[Pilati, Katia. 2021. "The effect of repression on protest" In Bojar, Abel, Theresa Gessler, Swen Hutter and Hanspeter Kriesi (eds.) Contentious episodes in the age of austerity. Studying the dynamics of government-challenger interactions. New York: Cambridge University Press, pp.190-210.]

\title{
The Effect of Repression on Protest
}

\author{
Katia Pilati
}

\begin{abstract}
In this chapter, we investigate how government repression affected challengers' protest mobilization. While most of the challengers' actions were peaceful, and violence basically non-existent, governments adopted some degree of repressive measures across all countries. Repression however, did not significantly alter the repertoire of actions which tended to remain moderate without showing any form of radicalization throughout the episodes. The only change in the forms of action due to repression concerned radical actions that were slightly reduced due to repression. This was especially apparent for Greece, where repression decreased the likelihood of confrontational actions, i.e. occupations by trade unions. The effect of repression changed across types of challengers and across specific dimensions of the context, too. Repression mainly affected institutional actors such as political parties whose participation in protests significantly decreased. In addition, repression had a stronger dampening effect on conventional actions under right-wing governments. Finally, repression dampened protests when no international actors intervened in domestic politics.
\end{abstract}

\section{Keywords:}

repression; anti-austerity mobilization; Europe; protests; radicalization 


\title{
Chapter 10
}

\section{The Effect of Repression on Protest}

\author{
Katia Pilati
}

\section{Introduction}

On May 5 and 6, 2010 Greece witnessed extensive protests including a fortyeight-hour nationwide strike and demonstrations in major cities. Protests were provoked by the passing of three austerity measures by the Greek parliament in February 2010, in March 2010, and finally in May 2010. The measures were part of the conditions for the $€ 110$ billion first E.U. bailout, acquired in order to solve the Greek government debt crisis. These events ended with clashes between the police and anti-austerity protesters, during which the police made widespread use of tear-gas and flash bombs, and made multiple arrests. Three people died when some individuals set fire to a bank branch with Molotov cocktails, and tens of people were injured. One year later, the police once again made use of violence against protesters at the May 11 demonstrations. This was a few days before the Greek Indignant Citizens Movement on May 25, 2011 started to protest in major cities across Greece. In June 2011, in concomitance with the government discussions on the midterm adjustment program and additional austerity measures (the adjustment program was later passed on June 29, 2011), police 
clashed with demonstrators numerous times - again, making excessive use of tear-gas.

In France in 2010, between October 14 and 18 more than three hundred students protesting against the Sarkozy-Fillon austerity package, were arrested and injured by the police. These events saw the occurrence of many accidents, such as that of a student who was severely injured by a flash ball.

In Spain, in July and August 2011, during Zapatero's negotiations on the second bailout, the Spanish national police collided with the 15-M movement, named after the beginning of the demonstrations on May 15, 2011, the Indignados, and dismantled their camps in Las Palmas, Santa Cruz de Tenerife, Palma de Mallorca, Manacor, Badajoz, and Castellón. Police actions were also reported in the Sol camp in Madrid.

Repressive measures such as those listed above touched most European countries affected by the crisis where anti-austerity protests developed. However, systematic empirical evidence on the effects of repressive measures adopted by governments against anti-austerity protesters during the Great Recession- namely, on their repertoire of actions - is still lacking (for single case studies however, see Sotirakopoulos and Sotiropoulos 2013; Portos Garcìa 2016).

While in Chapter 9 we examined government repression as a response to challengers' actions, in this chapter, by acknowledging that the repressiondissent nexus is two-sided, we analyze the other side of the relationship. We investigate how anti-austerity protesters in European countries reacted to the 
governments' repressive measures to suppress their challenges during the Great recession. This chapter thus aims to answer the following research questions: What were the effects of government repressive measures on the challengers' responses? Did the challengers' repertoire of actions change accordingly? Did repressive measures silence protests, did they lead to violent reactions or to an increase in peaceful and nonviolent political debates and interactions?

We shall explore the sequence of interactions, broadly examined in Chapter 8, by taking a closer look at the impact of repression on diverse forms of mobilization, and examining in greater depth the challengers' forms of mobilization presented by Gessler and Hutter in Table 4.2.1 We contend that the link between repression and protests depends on the specific form of action considered and on the type of challengers engaged in protests. We shall also argue that the repression-protest nexus is conditional on certain context characteristics -based on the concept of political opportunity structure (POS) as expressed in the literature. By studying such dynamics, this chapter aims to clarify crucial issues related to the democratic functioning of European countries. Repression threatens democracy, to the degree that it aims to contain and hinder the possibilities for a multiplicity of civil-society organizations - unions as well as oppositional political parties - to participate in protests and thus to engage fully in the political sphere. In this framework, our first contribution is to uncover how repression has an impact on shifts in challengers' repertoire of

1 The variables used for identifying forms of mobilization in Table 5.2 and in this chapter differ slightly. Table 5.2 lists forms of mobilization solely involving procedural actions. Whenever they are mentioned in our sources, the variable in this chapter refers to all forms of mobilization. 
actions. Second, we shall examine this relationship using CEA, thereby overcoming the limitations of large-N studies as well as those of single-case studies and narrative approaches. We can thus focus on a large number of cases related to various forms of government repression and challengers' protests in a way similar to the epidemiological approaches Tilly used (Tilly 2008: 206).

Furthermore, we are able to reconstruct the particular interactions within a specific time sequence. Thus, when focusing on a large-N empirical dataset, we will not lose out on what actually occurs during such interactions since we are able to trace them back to specific actors and to the specific action repertoires.

\section{Explaining Changes in Challengers' Repertoire of Actions through Repression}

In addressing the question of what accounts for changes in challengers' repertoire of actions, and under what circumstances changes in the character of contention occur, Tilly (2008) argues that performances and repertoires vary as a result of the influence of a given campaign - successful or not - on the next campaign. ${ }^{2}$ This kind of influence operates through alterations in three channels: the political opportunity structure (POS), available models, and connections among potential actors. We focus on changes occurring through alterations of the POS, positing that a campaign can transform the POS and therefore alter the subsequent campaign. As Tilly (2008) argues, the POS is affected by previous campaigns in diverse ways: by bringing new actors into the regime; by

${ }^{2}$ Campaigns are defined by Tilly (2008) as coordinated series of episodes involving similar claims on similar or identical targets. 
establishing new alliances between challengers and holders of power; by changing a regime's repressive policy. The latter was the main focus of Chapter 9.

In this chapter, we study how the repertoire of actions has been modified by examining the impact of changes in the POS implied in the use of repressive measures by governments. Repression is considered as "any action by another group which raises the contender's cost of collective action" (Tilly 1978: 100) and, therefore, it closes, limits, and hinders challengers' opportunities to mobilize in the political sphere. ${ }^{3}$ Forms of repression include nonviolent state actions such as sanctions, restrictions of liberties, as well as forms of control such as arrests, tear gas, and shootings. Next to these actions, scholars have emphasized that government threats and negative evaluations of challengers may further contribute to the closing of opportunities to mobilize, given that they represent forms of symbolic repression. Discursive frames by elites and institutional actors define a cultural set of opportunities referred to as a discursive opportunity structure (DOS) (Koopmans et al. 2005); this shapes the challengers' political actions by attributing to them and/or denying them political legitimation and recognition.

As already mentioned in Chapter 8, the way that repression affects protests is still largely debated in the literature, despite its study having long informed the analysis of contentious politics in several social science areas of study, including social movements, revolutions, ethnic conflicts, civil wars, and

${ }^{3}$ In this case, repression is thought of as a contraction of opportunities. As mentioned in Chapter 9, this claim was reformulated later, by Tilly himself (2005), who argued that the effect of repression is less straightforward. When repression is perceived as a threat, it may also induce a radicalization of insurgents. 
civil resistance. Researchers have proposed various hypotheses on the repression-dissent nexus. However, they have been divided with regard to the direction of the repression effect, and have only to a limited extent succeeded in offering coherent and consistent interpretative patterns (Earl 2011). As Lichbach has observed (1987: 271) "what is unknown is how repression both escalates and deters dissent." Following rational action theories, researchers claim that harsh repression depresses protest mobilization. From this perspective, engagement in action is determined by careful cost-benefit calculations by potential participants. Individuals are likely to participate if the benefit from participating is greater than its costs (Oberschall 1973). In contrast to this hypothesis, others emphasize that harsher coercion accelerates protests. Under such circumstances, a core of the opposition group might become dedicated to organizing reactive protests (Lichbach 1987: 270). Researchers have also put forward a nonlinear link between repression and protest mobilization, suggesting a convex U-shaped relationship (Lichbach and Gurr 1981). Under this model, both low and high levels of repression lead to high levels of protest, whereas protest is at its lowest levels during medium-level repression. Other authors have suggested a concave or inverted U-shaped relationship: Gurr (1970: 238) argues that the threat and severity of coercive violence may increase the anger of dissidents and intensify their opposition. Yet, this occurs up to some threshold beyond which fear predominates. Under very repressive regimes, the costs and risks associated with protest and rebellion instill fear, terror, and distress in the population and therefore prevent the open display of dissent. 
Following this reasoning, protesters can be mobilized best under semirepressive regimes.

\section{The Link between Repression and Protests: Considering Forms of Protests and Types of Challengers}

Past studies on the policing of protests in Italy and Germany in the 1970s claimed that repression moderates peaceful protests while it intensifies violent protests (della Porta 1995). In the increasingly repressive context of Italy in the 1970s, mass protests and peaceful demonstrations decreased after reaching a peak in 1971, while political violence increased throughout the 1970s (Tarrow 1989). Along the same line of reasoning, Lichbach (1987: 285) proposed that "an increase in a government's repression of nonviolence will reduce the nonviolent activities of an opposition group but increase its violent activities." According to this argument, repression radicalizes protests, and therefore has a positive effect on the use of political violence. Political violence is, however, only one form of action within the broader repertoire of contention that challengers may engage

in. Under authoritarian regimes, protesters often redirect their activities toward more moderated repertoires of action, since these are often perceived as less threatening. Challengers may also turn to transnational actions outside their country, or use strategies aimed to self-contain their protests (Pilati 2016). In many countries of the Middle East and North Africa, as a response to the prohibition of protests, activists often chose itineraries of deradicalization by committing themselves to forms of social, cultural, intellectual, and artistic 
activities (Duboc 2011). Following these studies, we can expect repression to have an effect on the repertoire of action, an effect that is likely to depend on the type of action deployed by the challenger. On one hand, we follow the simplest hypothesis and suggest that repression is likely to remove the challengers' opportunities to mobilize. This is in line both with the POS perspective -arguing that closing opportunities dampens protests - and with a rational choice model, given that repression implies higher costs for challengers to engage in protests. We therefore expect that repression reduces most forms of protest (repression works hypothesis). On the other hand, we expect repression to polarize protests: that is, to increase both the challengers' engagement in moderate and conventional forms of actions and in violent action forms (polarization hypothesis).

Following the argument in the previous chapter, we also expect that repression has a different effect depending on which actors challenge the government's proposals. The contentious episodes analyzed in this book involve diverse actors, with varying degrees of institutionalization, the most institutional being international and government bodies and political parties, and the least being civil-society organizations (CSOs), including social-movement organizations. We expect that repression has a stronger dampening effect on the protests by the least institutionalized actors - CSOs or even trade unions - and a weaker dampening effect on protests by more institutional actors, such as political parties or governmental actors. In particular, as proposed in Chapter 9, we expect repression to be harsher when contentious episodes are driven by the least institutionalized actors, such as civil-society organizations, than when they 
are mainly driven by more institutionalized actors, such as political parties (civilsociety organizations hypothesis). ${ }^{4}$ Institutional actors, beside being more likely to be involved in electoral politics, are perceived as more legitimate, even if they intervene in the protest arena. Furthermore, they are likely to perceive governmental repression as less intimidating and/or threatening compared to the least institutionalized actors.

In contrast to this hypothesis, we may also expect that the most institutional actors are used to adopting routine actions and interact more often in the parliamentary and electoral arena than in the protest arena. Consequently, we expect that if they resort to protest, which is "unusual" for them, and meet with governmental repression, they will quickly retreat from such activities. In other words, we expect that the dampening effect of repression on protest is stronger when political parties are the dominant challengers, as they are used to engaging in institutional politics and are less prepared to interact and respond to government repression in the protest arena (political-party hypothesis).

\section{The Role of the Context in Moderating the Relationship between Repression and Protests}

Preexisting context conditions may also affect the way repression has an impact upon challengers' opportunities to engage in protests. In those countries where challengers are accustomed to repressive measures, in less democratic regimes, challengers may anticipate the adoption of repressive measures by the

${ }^{4}$ In the previous statement, the focus was on single actors, while here the focus is on the episode-level actors' configurations as in Kriesi's Chapter 9. 
governments, in contrast to challengers operating in contexts where governments tend to promote negotiations, dialogue, and cooperation with challengers. Likewise, governments that are perceived as untrustworthy, or political systems that are unstable, may equally provoke different reactions by challengers responding to government repression, compared to responses by challengers operating in more trustworthy and stable contexts.

Considering the context, we first examined the effect of repression on protests for the Greek case in particular, given that Greece was the country where the most anti-austerity protests took place (Kriesi et al. 2020). Second, we analyzed the moderating effect of two of the least stable dimensions of the POS the political orientation of the cabinet in charge and elite alliance.5 The literature has widely acknowledged the effects of the political orientation of the cabinet on protests. Left cabinets are expected to stimulate the participation of groups in politics, given that they will appeal to constituencies of the civil society to build as broad an electoral coalition as possible and facilitate challengers' mobilization.

When, however, left cabinets are in power, the need for mobilization may decrease because of anticipated possibilities of reform in their favor (Kriesi et al. 1995: 59-60). Depending on whether government orientation is left or right, challengers may also react differently to repression. With left cabinets in power, challengers may perceive repression as less threatening, and they may consider

${ }^{5} \mathrm{Next}$ to these dimensions, we have also tested the conditional impact of both more-stable dimensions of the POS - namely, the type of democracy - and of other less stable dimensions of the POS, such as the degree of political stability and the type of electoral system, specifically testing whether a higher degree of proportionality or a more majoritarian system had some moderating effect. However, neither of these dimensions had a significant moderating effect or models did not provide reliable estimates. 
governments as possible allies. This may be even more true for challengers engaged in anti-austerity protests during the Great Recession, given that many of them were driven by leftist ideologies. We therefore expected that the dampening effect of repression on protests might be weaker under left cabinets (left cabinet's reinforcing hypothesis). Alternatively, because challengers may not anticipate repression from left cabinets and, consequently, may be caught off guard when such governments nevertheless resort to repression, the dampening effect of government repression on protests might actually be stronger under left cabinets than it would be under right cabinets from whom repression is more expected (left cabinet's dampening hypothesis).

The second dimension of the POS that we examined refers to alliances. In particular, when national governments build ties with international actors, they may be reinforced in their original plans. Thus, in the case of anti-austerity protests, international actors have often been perceived as having been at the origin of many austerity measures themselves. This was the case in Greece, where the European Commission (E.C.), the European Central Bank (E.C.B), and the International Monetary Fund (I.M.F.), the so-called Troika, imposed austerity programs on the Greek government. Under such circumstances, the dampening effect of repression on protests was likely to be stronger, since challengers were likely to perceive more constraints on protest mobilization (constraint hypothesis). The situation is likely to be very different when international actors ally themselves with challengers, as in the case of supranational institutions building coalitions with opposition parties against national governments. Under such circumstances, coalitions between challengers and international actors are 
likely to be perceived as numerically strong, and worthy to be listened to; international actors may heighten challengers' legitimacy and symbolic recognition, overall improving challengers' WUNC - worthiness, unity, numbers, and commitment (Tilly 2006: 53). Alliances with international actors, endowed with many symbolic and material resources, are therefore likely to provide challengers with an easier access to politics, thanks to the provision of resources that challengers may lack. We thus expected challengers' alliances with international actors to affect the impact of repression on protests by opening opportunities. Consequently, repression would have a lower dampening effect on protests when challengers ally themselves with international actors (international ally hypothesis). Since in our episodes international actors were mostly institutions, we expected repression most likely to have a dampening effect on the most conventional forms of protest actions rather than on other forms of protest, given that institutional actors are more likely to engage in conventional actions (conventional actions hypothesis).

\section{Methods}

\section{Dependent Variables}

In the subsequent analysis, the dependent variable consists of the various forms of protest mobilization. In our first step, we investigated challengers' engagement in any form of protests. Next, we delved into the analysis of four specific forms of protests: conventional actions, strikes, demonstrative actions, and the most disruptive forms of actions - confrontational and violent actions - 
which we refer to as radical actions. The category of conventional actions includes direct democratic actions, such as legal procedures, proposals to change the legislation, initiations of referenda, and public consultations. Together with petitions these actions made up the majority of institutional forms of protest. Nondisruptive and disruptive protests, referred to in Chapters 8 and 9, were disaggregated into specific types of protests. In particular, we disaggregated disruptive actions and distinguished radical actions (confrontational and violent actions) from demonstrations. All the dependent variables are binary variables $(1=$ challenger action takes the form in question; $0=$ other challenger action $)$. We examined how repression affects the different forms of protest mobilization, including both outright actions and verbal statements. ${ }^{6}$

\section{Main Independent Variables}

Our main independent variable is government repression. Following the previous two chapters, we considered the lagged actions by government, using a binary variable focusing on repression $(1=$ government repression; $0=$ other government action). Examples of repressive actions included the use of legal provisions against challengers, police clashes, and arrests of demonstrators. Repressive verbal statements were claims aimed demonizing, depreciating, or

${ }^{6}$ This simplification of the analysis is imposed by the lack of data. As in the previous chapter, we quickly met the limits of the number of cases once we distinguished between different action forms and/or introduced context characteristics into the analysis. While the previous chapter chose to reduce the number of action forms, the focus on action forms in this chapter imposed another type of simplification. 
not recognizing challengers, including denouncing specific party decisions or criticizing workers such as public employees who resist wage cuts.

The conditional effects of the POS variables on the repression-protests link were tested by adding interactions between repression and POS variables. The latter are country- or episode-specific. Interactions were added separately, one in each model.

Control variables included in the models are the following: lagged actions by third parties, a binary variable $(1=$ third parties supported challengers; $0=$ did not do so); challengers' lagged actions, a binary variable $(1=$ challengers' lagged action is of the same type; $0=i$ it is not of the same type); ${ }^{7}$ country fixed effects; sequence length and squared sequence length.

\section{Models}

To test our hypotheses, we followed the same procedures as in the previous chapters. Given that our dependent variables are binary variables, we estimated logit models with challengers' reactions (different types of protests) as the dependent variables and the lagged government actions - repression - as the main independent variable. We estimated logit regression models that take into account the multistage research design, and the correlation of data within episodes and countries. While the research design has a four-level structure (with actions at level 1, nested within sequences at level 2, within episodes at level 3, and countries at level 4), we used a cluster option, with the clustering

7 The model predicting the probabilities of engaging in any type of protest form includes the variables on challengers' lagged actions as coded in Chapters 8 and 9. 
variable accounting for the episode. ${ }^{8}$ We estimated the models, pooling all episodes together. Models first tested the effect of repression on different types of protests, thus testing the repression works hypothesis and the polarization hypothesis; second, models considered different types of challengers, thus testing the civil society organizations hypothesis and the political party hypothesis. Then, models tested the interaction effects, addressing the left cabinet's reinforcing and the left cabinet's dampening, as well as the constraint, the international ally, and the conventional actions hypotheses. Before turning to hypotheses testing, however, we shall describe levels and types of protests used by challengers across European countries between 2008 and 2016 .

\section{Results}

\section{Protests during the Great Recession: Levels and Forms}

Table 10.1 focuses on challengers' forms of mobilization. It illustrates the distribution of challengers' actions or verbal statements, focusing on those in which a specific form of protest mobilization has been explicitly mentioned.

\footnotetext{
${ }^{8}$ We used the vce (cluster clustvar) STATA option that indicates that the actions were independent across the episodes and countries but were not necessarily independent within those groups. This option specifies that the standard errors allow for intragroup correlation, relaxing the usual requirement that the observations be independent.
} 
Table 10.1

Challengers' engagement in different forms of protest mobilization across

countries (row \%)

\begin{tabular}{|c|c|c|c|c|c|c|c|c|c|}
\hline \multirow[t]{2}{*}{ Country } & \multirow{2}{*}{$\begin{array}{l}\text { Other } \\
\text { actions }\end{array}$} & \multicolumn{5}{|c|}{ protest (actions and threats) } & \multirow{2}{*}{$\begin{array}{c}\text { Total } \\
\%\end{array}$} & \multirow{2}{*}{$\begin{array}{c}\mathbf{n} \\
\text { (protest } \\
\text { and } \\
\text { other } \\
\text { actions) }\end{array}$} & \multirow{2}{*}{$\begin{array}{c}n \\
\text { (protes }^{n} \\
\text { t only) }\end{array}$} \\
\hline & & $\begin{array}{l}\text { Conven } \\
\text {-tional } \\
\text { actions }\end{array}$ & Strikes & $\begin{array}{l}\text { Demon- } \\
\text { strations }\end{array}$ & $\begin{array}{l}\text { Con- } \\
\text { front- } \\
\text { ational }\end{array}$ & $\begin{array}{l}\text { Violent } \\
\text { actions }\end{array}$ & & & \\
\hline Greece & 34.8 & 5.5 & 28.4 & 19.1 & 10.8 & 1.5 & 100.0 & 472 & 308 \\
\hline France & 40.0 & 1.1 & 34.4 & 17.8 & 5.6 & 1.1 & 100.0 & 90 & 54 \\
\hline Portugal & 40.8 & 21.0 & 15.7 & 22.3 & 0.3 & 0.0 & 100.0 & 319 & 189 \\
\hline Poland & 43.4 & 31.9 & 0.0 & 24.8 & 0.0 & 0.0 & 100.0 & 113 & 64 \\
\hline Romania & 48.8 & 21.5 & 9.9 & 18.6 & 1.2 & 0.0 & 100.0 & 172 & 88 \\
\hline Hungary & 51.5 & 22.0 & 5.3 & 21.2 & 0.0 & 0.0 & 100.0 & 132 & 64 \\
\hline Germany & 56.1 & 43.9 & 0.0 & 0.0 & 0.0 & 0.0 & 100.0 & 41 & 18 \\
\hline Spain & 57.1 & 3.5 & 5.2 & 32.9 & 1.3 & 0.0 & 100.0 & 231 & 99 \\
\hline Latvia & 57.3 & 15.5 & 3.6 & 21.8 & 1.8 & 0.0 & 100.0 & 110 & 47 \\
\hline Ireland & 75.0 & 5.5 & 4.8 & 14.6 & 0.2 & 0.0 & 100.0 & 440 & 110 \\
\hline Italy & 77.2 & 2.3 & 8.2 & 9.6 & 0.5 & 2.3 & 100.0 & 219 & 50 \\
\hline U.K. & 78.7 & 7.9 & 2.8 & 8.8 & 0.9 & 0.9 & 100.0 & 216 & 46 \\
\hline Total & 55.5 & 11.2 & 11.7 & 18.4 & 2.7 & 0.6 & 100.0 & 2,555 & 1,137 \\
\hline
\end{tabular}

a includes all challengers' actions

$\mathrm{b}$ includes conventional actions, strikes, signatures, demonstrations, confrontational, and violent protests

The table shows that approximately half of challengers' actions and verbal statements involved some form of protest mobilization. While Greece and Ireland show the highest number of challengers' claims, Greece, Portugal, and France were the countries in which at least 60 percent of all challengers' claims implied some form of protest mobilization. Considering the absolute number of protests, and confirming previous studies, Greece, Portugal, Spain, and Ireland were the countries showing the largest number of forms of protest mobilization, while Germany was the country with the smallest number of protests.

Most forms of protest mobilization were public demonstrations and strikes, accounting, respectively, for 18.4 and for 11.7 percent of all claims by challengers. Fewer challengers engaged in more conventional channels of 
participation: 11.2 percent of all political claims were conventional actions, of which 2.0 percent were petitions. While in most European countries challengers mainly engaged by demonstrating in the streets, in France and Greece challengers mostly engaged in strikes. The latter include the pension reform strikes that occurred in September and October 2010 in France, involving both the public and private sectors, and the two-day general strike staged by trade unions in Greece on June 28 and 29, 2011 against the midterm adjustment program, a new package of deeply unpopular austerity measures that was passed at the end of the month.

In contrast, in Germany conflict between challengers and authorities was both much more limited and restricted to the most conventional channels of participation. Conflict there largely took place in the institutional and partisan arena through actions such as handing in complaints to the constitutional court or voting against government initiatives. Challengers' actions included, for instance, a petition by the populist and Eurosceptic Alternative for Germany, AfD, in July 2015 against the E.U.'s planned bailout of Greece. Neither strikes, nor demonstrations, nor more radical actions were ever observed in Germany during the economic crisis as far as the selected episodes are concerned.

Only 3.3 percent of all public claim makings involved radical actions: that is, either confrontational or violent actions. More specifically, violent actions only represented 0.6 percent of all 2,555 challengers' claims. In other words, only fifteen violent protests were reported during the contentious interactions that occurred in the twelve European countries from 2008 to $2016 .{ }^{9}$ Considering that

9 This figure only concerns the percentage of violent actions that were actually reported by the media outlet used as sources of our data. Given that 
we have examined contentious interactions that occurred during sixty episodes that concerned key policy proposals related to the great economic crisis essentially austerity packages - we can claim that anti-austerity protests were definitely nonviolent actions. Confrontational actions were more present than violent actions during the contentious episodes, although still representing quite limited and sporadic events, accounting for 2.7 percent of all challengers' claims. Almost half of the violent actions occurred in Greece; likewise, three quarters of the confrontational actions occurred in Greece.

Given the exceptional characteristics of the Greek case, we propose to have a closer look at the contentious episodes in Greece. Figure 10.1 shows the daily count of protests and repressive measures during the five episodes in Greece. ${ }^{10}$ Considering the pattern of protests, the figure suggests that the five episodes were part of a single wave of contention. In particular, as argued by Kriesi et al. (2020: ch. 4), the three first episodes in $\mathrm{z}$ (the first bailout, the midterm adjustment, the second bailout) mark three different phases of the Greek wave of contention. The first, focusing on economic issues, occurred in 2010, mostly staged by unions and the radical left; the second occurred in summer 2011 in concomitance with the appearance of the Greek Indignant

violent acts tend to find considerable public resonance and to be reported by newspapers more frequently than the least contentious forms of protests, it is unlikely that these percentages are underestimated. Furthermore, the peak of violent events in southern Europe, where most of the protests took place, occurred in the early phase of the crisis that is not included in our episodes. Specifically, in Greece it occurred at the end of December 2008 in the aftermath of the shooting of a teenager by the police (Kriesi et al. 2020: chs. 4 and 5 ).

10 The daily count of protests is only a rough measure and does not take into account important details such as the number of participants in the events. 
Citizens Movement and was characterized by semi-spontaneous and innovative forms of protests; the third, between October 2011 and February 2012, marked a continuation of the previous wave and was characterized by the intensification of low-level unions actions (see Chapter 12 for an in-depth analysis of the Greek case). The demobilization phase of the Greek wave of contention unfolded during the last two episodes examined, the ERT TV shutdown and the third bailout, during which the number of daily actions clearly diminished.

During the second bailout, next to demonstrations and strikes, the repertoire of actions expanded and protests included some radical actions (as shown in Figure 10.2). In our episodes, most violent actions occurred during the second bailout negotiated between early October 2011 and February 2012. The protests during this period resulted in violent confrontations between anarchists and the police. The clashes with the police erupted after the demonstrations in February 2012 by the General Confederation of Greek Workers (GSEE) and the Civil Servants' Confederation (ADEDY) (see in Figure 10.2 the peak of confrontational/violent actions at the end of the episode concerning the second bailout). Considering confrontational actions, a few occurred during the first bailout in May 2010, concerning, inter alia, the occupation of the Acropolis by members of the Greek Communist Party (KKE). Most confrontational actions were employed during two episodes, the second bailout (October 2011-February 2012) and the ERT TV shutdown (JuneNovember 2013). During the second bailout in January 2012 protesters occupied Syntagma Square and other public buildings, such as the law school. Most occupations, however, occurred during the shutdown by the Greek parliament of 
the country's public broadcasting service, ERT, in June 2013 that led to a reshuffling of the cabinet. The shutdown was a major event among others in summer 2013. During this period, in addition to the ERT TV shutdown, the country witnessed the passage of reforms related to yet another austerity package, imposed by the ongoing E.U.-I.M.F. bailout. In particular, the first reform was approved by the Greek parliament on April 28, 2013 and the second one on July 17, 2013. In this context, the occupation of ERT headquarters by its employees started in the middle of June 2013 and ended in early November 2013. These events also triggered the implementation of broadcasting activities on alternative platforms, and prompted Syriza M.P.s to confront the police in their effort to enter the ERT headquarters. The two peaks in the otherwise flat line in the right-hand graph of Figure 10.2 precisely signal the presence of occupations during the TV shutdown.

Figure 10.1: Daily count of repressive measures and of protests in Greece across contentious episodes 

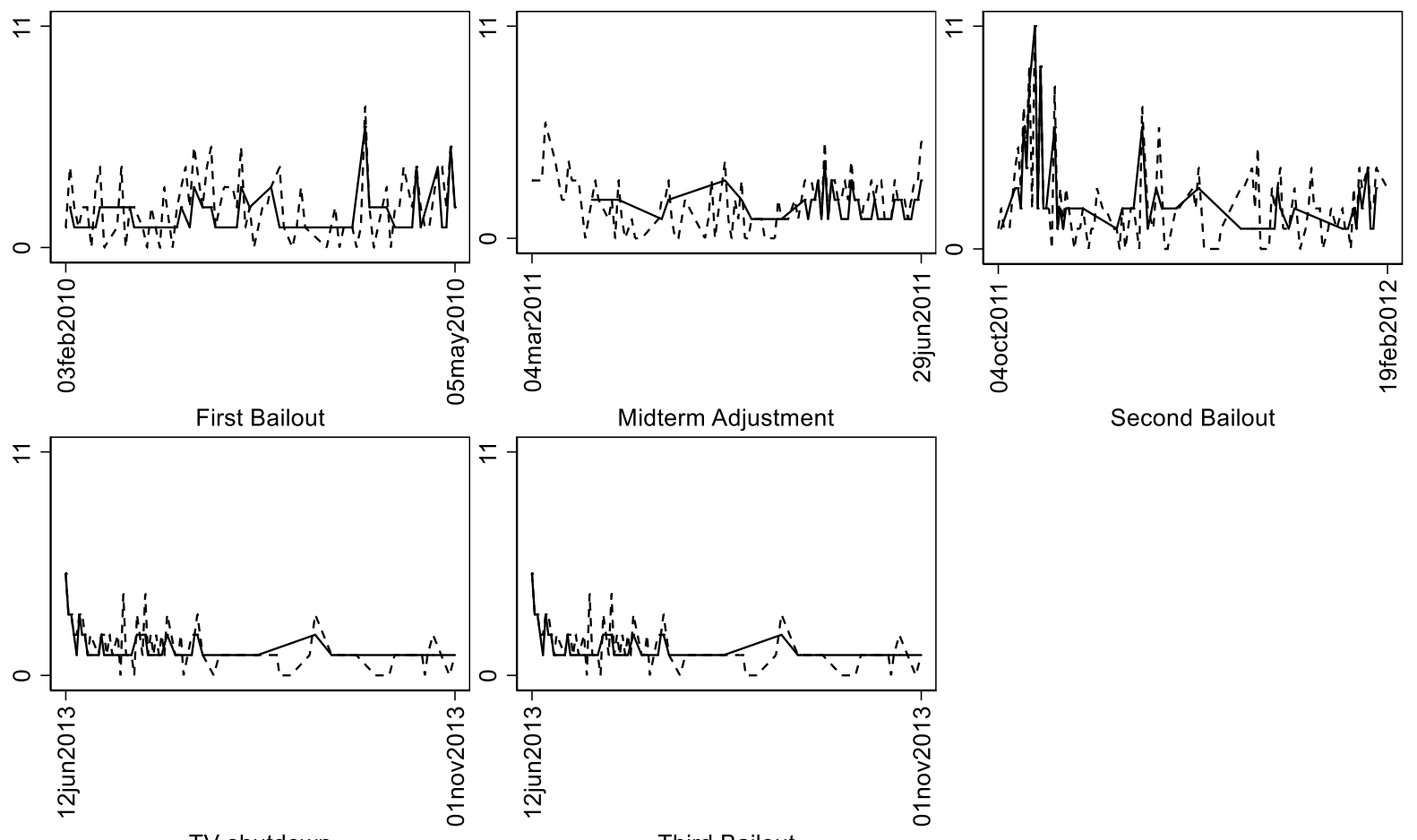

Second Bailout

TV shutdown

Third Bailout

repression protests

Figure 10.2: Daily counts of protests and radical actions (confrontational and violent actions) during the Second bailout and the TV shutdown in Greece

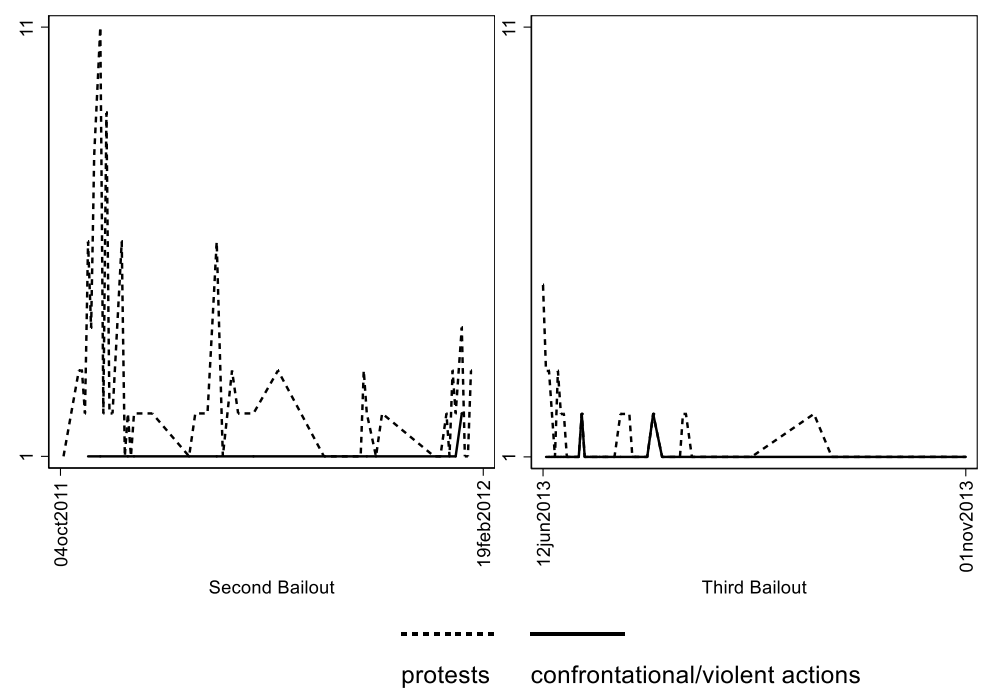


Turning to the actors engaged in protest forms of mobilization in Europe between 2008 and 2016, analyses (not presented here) show that, with the exclusion of conventional actions, trade unions coordinated, organized, or participated in more than 60 percent of all the forms of protest observed. Trade unions were especially active in France, where they represented around 70 percent of all challengers' forms of protest mobilization, in line with the historically strong class cleavage in this country, and in Greece, where they represented the main challenger in more than 65 percent of all forms of protests. As expected, trade unions were the main actors of the most notable and traditional form of action in the labor field, strikes, as they accounted for around 92 percent of the strikes that occurred after 2008. Trade unions, however, also widely engaged in demonstrations throughout the crisis, and after classic civilsociety organizations represent the second actor mainly engaged in demonstrations. This suggests an engagement of trade unions beyond workplace mobilization and is in line with studies that have highlighted the presence of broad coalitions during the Great Recession. These networks were active in demonstrations, and in open public spaces such as streets, squares, and parks, and focused on cross-cutting issues and cross-border initiatives such as social exclusion and austerity measures (Ancelovici 2011; della Porta 2015).

\section{Repression During the Great Recession}

Governments had various options for interacting with challengers in the contentious episodes examined. These options spanned from repressing challengers to fully engaging in negotiations with them. As shown in Table 4.2, 
7.2 percent of government procedural actions were repressive measures. If we also consider threats related to repression, the same table shows that 32.0 percent of government's procedural claims depreciated challengers, and 7.1 percent failed to recognize them. If we compare the most extreme forms of actions by challengers and by governments - that is, violent actions and repression, respectively - the latter makes up a far larger share of government actions than violence in relation to challenger actions. Considering all countries, outright repressive measures included a limited number of actions in absolute terms as compared to other actions adopted by governments (43 repressive actions), while most repressive measures consisted in threats (232 threats including both depreciating and not recognizing challengers). As Table 10.1 demonstrates, in addition to Greece, only in Italy, France, and the U.K., were violent actions ever reported. These included the outbreak of disorder across the U.K. in November 2010 during student demonstrations against the government's higher-education plans and in Italy the violent contestations in early 2012 against the so-called Fornero pension reform (named after the Italian minister of labour, social policies, and gender equality), which was part of the austerity measures known as the "Save Italy" decree passed in December 2011.

In contrast, except for Hungary, some form of repression was present in all countries. The country employing the most number of repressive actions was Greece, where 32.6 percent of all repressive actions took place (fourteen actions and thirty-seven threats). Repression included violent police clashes with antiausterity protesters, arrests, use of tear gas, and the eviction of protesters occupying public buildings. 
The empirical analysis of the effects of repression on protest focuses on repression that preceded the challengers' protest mobilization within a sequence of interactions. To clarify, we only selected instances of repression-protest interactions such as the one that occurred during the 2013 ERT TV shutdown in Greece. On June 29, 2013 the police removed the ERT transmitter in Ymittos, a suburb of Athens, and clashed with demonstrators by arresting nine protesters. As a response to such repressive action, on June 30, ERT employees, ANTARSYA (the Front of the Greek Anti-Capitalist Left, a coalition of radical-left political organizations in Greece), and SPITHA (a political movement led by Mikis Theodorakis, a composer) engaged in protests against the ERT closure.

In most cases, repressive measures were not connected with protests in a sequence of interactions and, consequently, cannot directly represent factors associated with protest mobilization. The absence of protest by challengers after repression suggests that challengers may organize a reaction to counter repression through actions that may not explicitly and purposefully address a specific repressive measure or which take a long time for their organization and, consequently, may not be reported as directly linked to repression.

As shown by Figure 10.1, the pattern of daily protests and of lagged repressive measures used by governments in the Greek case partly overlap. This was clearly visible during some periods, such as during the end of the episode concerning the first bailout, at the end of the midterm adjustment, and at the beginning of the second bailout, where the peaks of the lines evidently overlap, suggesting that repression may have had some effect on protests. The next section will unfold this issue more clearly. 


\section{Repression and Types of Protests}

We shall first specifically examine how repressive measures impact upon different forms of protest (repression works and polarization hypotheses), note whether the impact changes depending on the type of challenger involved (civilsociety organizations and political party hypotheses), and then analyze whether the effect changes depending on specific conditions of the context in which protests emerge (left cabinet's reinforcing, left cabinet's dampening hypotheses, and constraint, international ally, and conventional actions hypotheses). ${ }^{11}$ For each model we calculated the predicted probabilities of protesting when governments repress and when they don't, and report the results in Figures 10.3 to 10.7. The full models based on which we calculated the predicted probabilities are reported in the Appendix (Tables A10.1 to A10.5). ${ }^{12}$

Figure 10.3 and Table A10.1 show that with the exception of radical actions, most forms of protest mobilization were not affected by government repression. The figure shows, however, that there is a significant and negative, although small, effect of government repression if radical, including violent, forms of protest mobilization have been observed.

Figure 10.3: effects of government repression on challengers' radical actions (Table A10.1 for full models)

11 The following analyses examine the impact of repression on all forms of protest mobilization, thus including actions and verbal threats or menaces. As already mentioned, we also examined protest actions only and show the results when significant.

12 From now on, we only show the figures when interaction terms are significant. For full analyses, the reader may turn to the models presented in Tables A10.2 ff in the Appendix. 


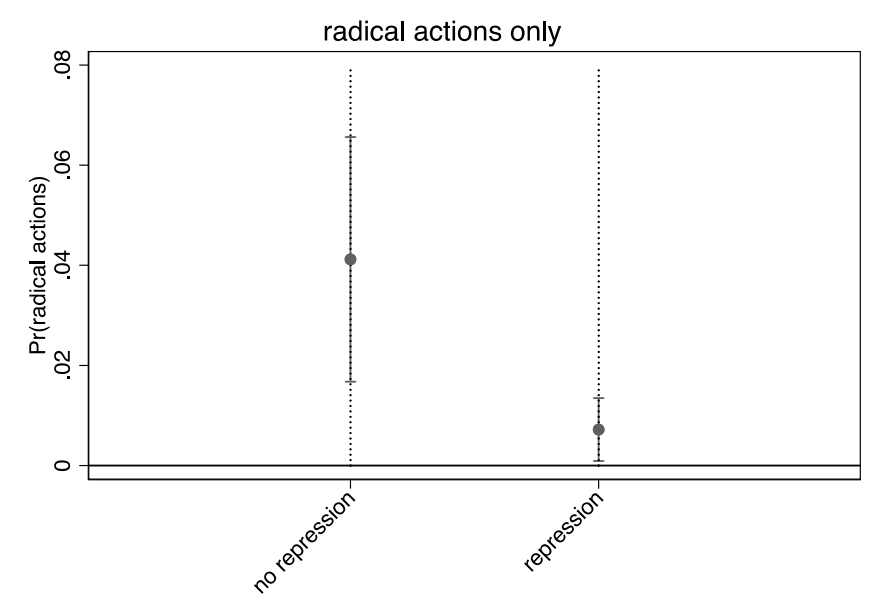

More specifically, when focusing only on actions, repression decreases radical actions by 3.3 percentage points (Figure 10.3), suggesting that the effect of repression depends on the form of protest considered, and the repression works hypothesis, which stipulates an overall dampening effect of repression on any form of protest, was not confirmed. Our findings also fail to confirm the expectations formulated in the polarization hypothesis suggesting that repression polarizes protests. Repression adopted during the Great Recession had neither a radicalizing nor a moderating impact on the action repertoire. This means that, despite the use of repression by governments, anti-austerity protesters did not ultimately adopt more violent and confrontational actions, while challengers adopted a peaceful repertoire of action throughout the contentious episodes analyzed, even after government repression. This result underscores the finding in Chapter 8 that the probability of disruptive challenger action is largely independent of what the government has done previously (see Figure 8.3). Once we distinguish between violent and confrontational actions on one side, and demonstrations on the other, we do find an effect of government repression. As suggested by these results, the slightly negative effect of 
repression on violent and confrontational actions is likely to be suppressed by the lack of a corresponding effect for (the much more numerous) demonstrations.

\section{Repression and Type of Challengers}

The civil-society organizations hypothesis and the political party hypothesis maintain that repression may have different effects on protests depending on the type of challenger. We tested these hypotheses by classifying episodes according to the prevailing type of challenger engaged in the interactions with governments within each episode. Following Chapter 9, we categorized challengers according to their level of institutionalization and specifically looked at the effect of protests when parties, trade unions, or civil-society organizations were the main challengers in the contentious episodes examined. Figure 10.4 shows that government repression significantly decreased engagement in any protests by the most institutionalized actors - parties, but not when trade unions or CSOs were the main challengers. When political parties drovee contentious episodes, repression reduced their protests, above all the demonstrations they organized, by 13 percentage points. These results confirm the political party hypothesis: There is a stronger dampening effect of repression on protests, particularly on demonstrations, in those episodes where the most institutional actors were the prevailing challengers, than in those episodes where other actors predominated. Figure 10.4 also shows that there was a dampening effect of repression on demonstrations when CSOs were the prevailing challengers, thus 
confirming the civil-society organization hypothesis as well (the effect is significant in Table A10.2, model 3).

Figure 10.4: Effects of government repression on challengers' protests, considering episodes classified according to actors' configurations (Table A10.2 for full models)
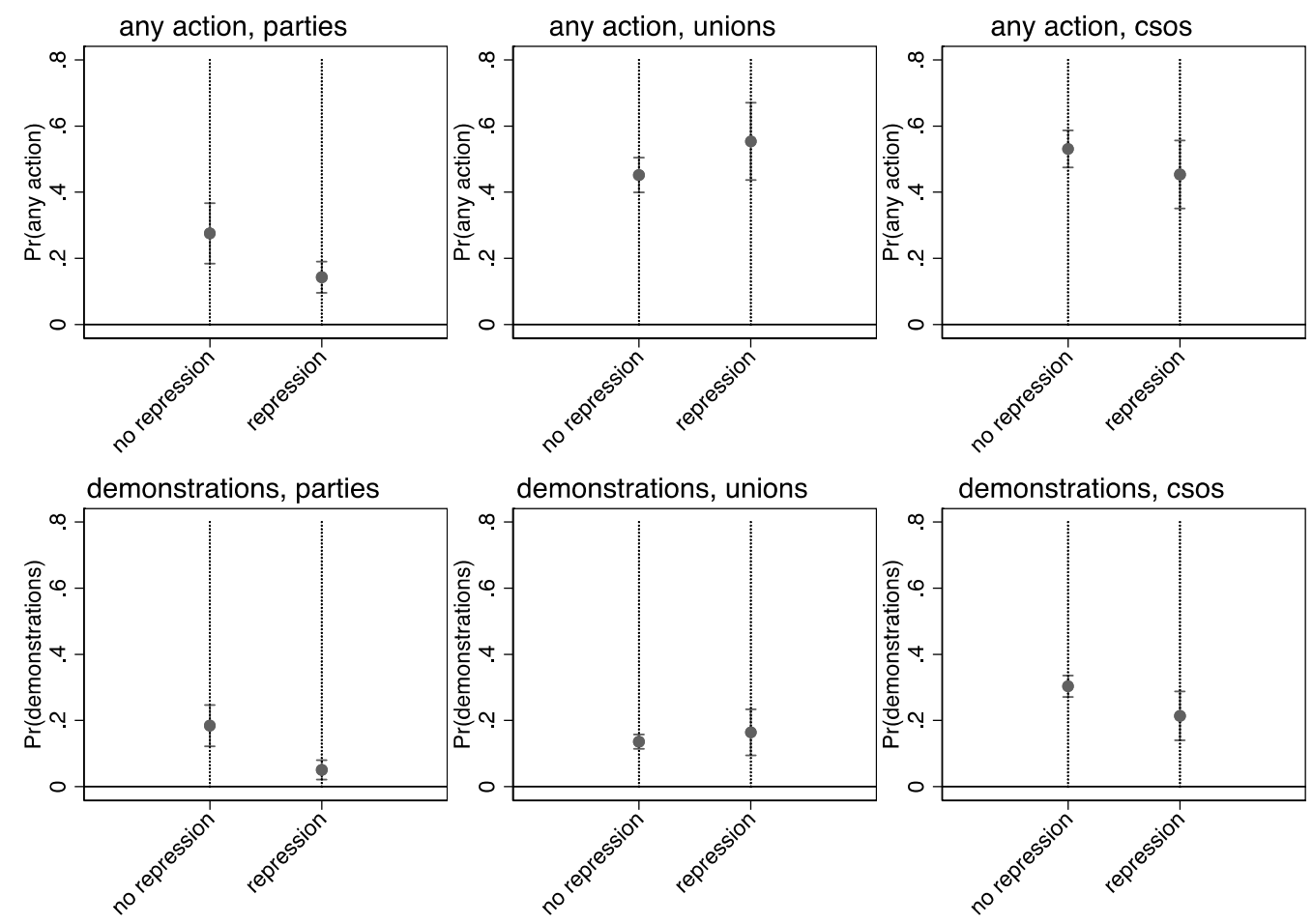

\section{The Conditional Impact of Context on the Effect that Repression Has on Protests}

We shall delve further into the analysis by focusing on how the effect of repression on protests may change depending on the context in which challengers operate. First, we shall look at the Greek case in more depth. As we already mentioned, it was in Greece that protest was most intense. Results for the Greek case (Figure 10.5) confirm that repression dampens radical actions 
(when considering actions only). Although findings were only marginally significant (see Table A10.3, model 5), radical actions diminished by around 10 percentage points due to repression. These results mainly concern trade unions, which engaged in more than 60 percent of all forms of protest mobilization examined in Greece and in more than 75 percent of all radical actions examined. Given the propensity of trade unions to engage in strikes, the traditional form of protest mobilization by trade unions, any form of repression by governments easily contained their engagement in more radical actions. In addition, Figure $\underline{10.5}$ shows that repression in Greece increased the challengers' overall protests by around 10 percentage points (by 17.5 percentage points when actions only are considered) and, more specifically, strike actions by 15 percentage points (the effects are significant as shown in Table A10.3).

Figure 10.5: effects of government repression on challengers' protests in Greece (Table A10.3 for full models)
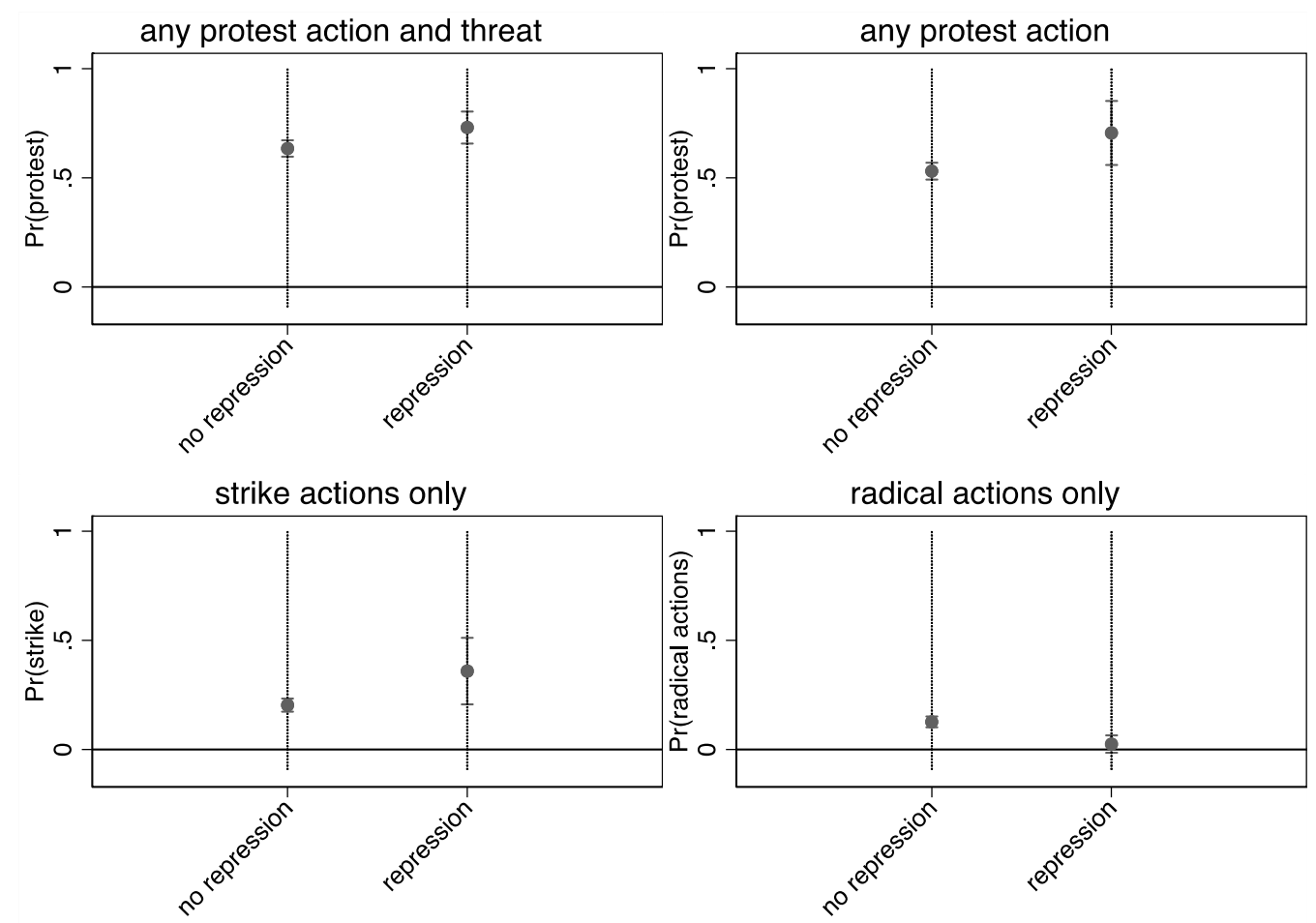
The analyses of the Greek case partly responded to our query about a moderating effect of the context in shaping the relationship between repression and protests. As it turned out, the repression-protest nexus was especially significant for the Greek case, whereas in most other countries challengers engaged far less in protests, generally, and rarely engaged in radical actions. ${ }^{13}$

We shall next turn to examine whether the context dependency of the repression-protests nexus is related to some specific dimensions of the POS. Figure 10.6 shows the moderating effect of the political orientation of the cabinet on the impact that repression has on protests. The graph on the left shows that there was a higher dampening effect of repression on conventional actions in countries where right-wing cabinets were in power in comparison to governments where there were left-wing cabinets. Repression decreased the challengers' conventional actions by around 4 percentage points when a rightwing cabinet was in power, in comparison to the change in the predicted probability when left-wing cabinets were in power that, in contrast, was positive (only slightly significant in model 2 of Table A10.4). The left-wing cabinet's reinforcing hypothesis (but not the left-wing cabinet's dampening hypothesis ) is thus confirmed, supporting the idea that the dampening effect of repression on protests is weaker under left-wing cabinets. However, this holds only for those moderated forms of protests, such as conventional actions, including petitions.

13 Due to the limited number of cases when considering protests in individual countries, we have limited the analysis of the effect of repression on protests to the Greek case. 
Figure 10.6: the moderating effect of the different political orientation of cabinets (Table A10.4 for full models)

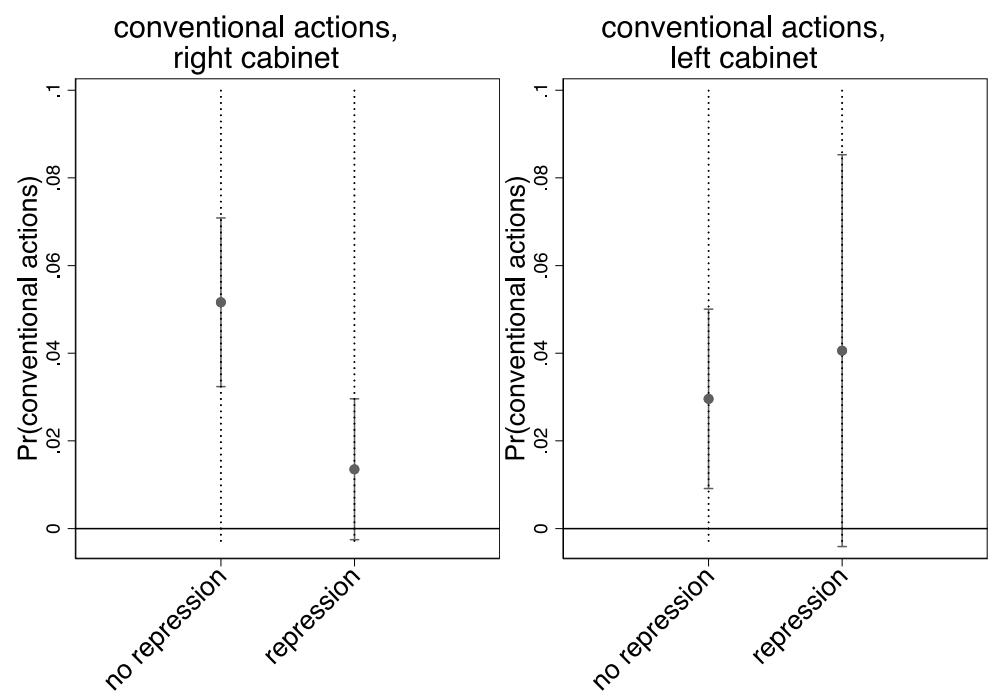

Figure 10.7 also shows that the effect of repression on protest actions was also moderated by the presence of international allies, but not in the direction we expected. In particular, the constraint hypothesis - on a stronger dampening effect of repression on protests when international actors ally with governments - was not confirmed, nor was the international ally hypothesis - on a weaker dampening effect of repression when challengers ally with international actors since the effect is not significant. The effects of repression on protests when either elites or challengers ally with international actors were not significant, but there was a stronger dampening effect of repression on conventional actions when no such alliances exist. Repression decreased the challengers' conventional actions by around 4.5 percentage points when no alliances existed. This result is in line with the conventional actions hypothesis. 
Figure 10.7: the moderating effect of different alliances of international actors with challengers (chall+) and governments (gov+) (Table A10.5 for full models) on the impact that repression has on protests
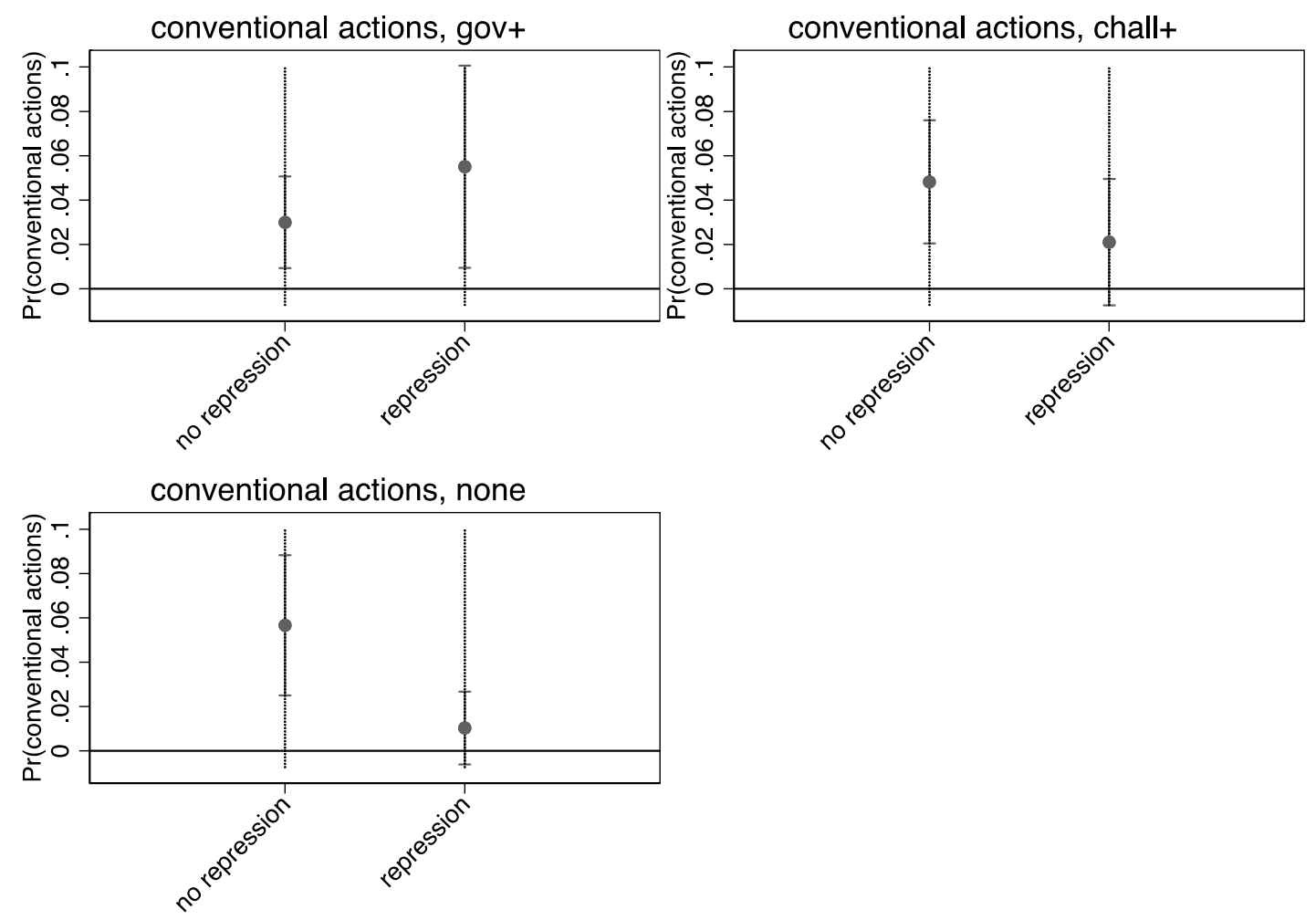

\section{Conclusions}

In this chapter we examined the effects of repression adopted by European governments on the protests which occurred in Europe from the beginning of the Great Recession in 2008 up to 2016. While most of the contentious episodes considered were peaceful, and violence basically nonexistent, all the governments adopted some degree of repressive measures. Repression, 
however, did not significantly alter the repertoire of actions, which tended to remain moderate without showing any form of radicalization throughout the episodes. Anti-austerity protests were largely nonviolent actions and, despite the use of repression by governments, challengers did not respond by adopting more violent and confrontational actions. They engaged in a peaceful repertoire of actions throughout the contentious episodes analyzed, even after government repression.

The only changes in the forms of protest mobilization due to repression concerned radical actions that were slightly reduced due to repression. This occurred especially in Greece, where repression decreased the likelihood of occupations by trade unions and induced trade unions to engage more in strikes. The effect of repression changed across types of challengers and also across specific dimensions of the context. Results also show that repression mainly affected institutional actors such as political parties, whose participation in protests significantly decreased. This was partly linked to the institutional nature of parties, and their tendency to engage in other political arenas such as electoral or parliamentary ones. The same was true for CSOs engaging in demonstrations. These findings thus suggest that repression hampers democracy to the extent that it decreases engagement by institutional actors and CSOs in the protest sphere, reducing their level of political participation - a crucial dimension of democracy.

The impact of government repression on protests also depended upon some conditions of the contexts where governments and challengers interacted. Besides country-level differences, illustrated by the effect of repression in the 
Greek case, the contingent conditions of the political system examined, namely the political orientation of the cabinet and alliances with international allies to some extent, affected the degree to which repression shaped challengers' repertoire of actions. In particular, for specific forms of protests, namely conventional actions, repression had a stronger dampening effect under rightwing governments. It is especially under right-wing governments that repression hampered democracy, specifically by decreasing levels of participation in conventional actions such as petitions. Finally, the effect of repression was a matter of isolation. Repression dampened protests when no international actors intervened in domestic politics, thus suggesting that repression works when government-challengers interactions are confined to the domestic and national arena of interactions. 


\section{Methodological appendix}

Table A10.1: effects of government repression on challengers' actions and threats (upper table) and on actions only (lower table)

\begin{tabular}{|c|c|c|c|c|c|c|c|c|c|c|}
\hline & \multicolumn{2}{|c|}{$\begin{array}{c}\text { Model } 1 \text { any form of } \\
\text { protest }\end{array}$} & \multicolumn{2}{|c|}{$\begin{array}{c}\text { Model } 2 \text { conventional } \\
\text { actions }\end{array}$} & \multicolumn{2}{|c|}{ Model 3 strikes } & \multicolumn{2}{|c|}{$\begin{array}{l}\text { Model } 4 \text { demonstrative } \\
\text { forms }\end{array}$} & \multicolumn{2}{|c|}{$\begin{array}{l}\text { Model } 5 \\
\text { radical actions }\end{array}$} \\
\hline & $\mathrm{b}$ & se & $\mathrm{b}$ & se & $b$ & se & $b$ & se & $b$ & se \\
\hline \multicolumn{11}{|l|}{ Actions and threats } \\
\hline government repression & -0.085 & $(0.286)$ & -0.784 & $(0.481)$ & 0.306 & $(0.455)$ & -0.341 & $(0.243)$ & $-0.590^{* * *}$ & $(0.160)$ \\
\hline third party support & 0.261 & $(0.288)$ & -0.499 & $(0.656)$ & $1.199^{* *}$ & $(0.386)$ & -0.160 & $(0.278)$ & -0.869 & (0.748) \\
\hline sequence length in levels & 0.005 & $(0.049)$ & 0.059 & $(0.086)$ & 0.075 & $(0.074)$ & -0.058 & $(0.043)$ & -0.039 & (0.068) \\
\hline sequence length squared & -0.001 & $(0.002)$ & -0.002 & $(0.003)$ & -0.004 & $(0.002)$ & 0.001 & $(0.001)$ & 0.001 & $(0.002)$ \\
\hline \multirow{2}{*}{\multicolumn{11}{|c|}{$\begin{array}{l}\text { Challengers' lagged action (none) } \\
\text { (REF) }\end{array}$}} \\
\hline & & & & & & & & & & \\
\hline Cooperation & 0.244 & $(0.400)$ & & & & & & & & \\
\hline Non-radical & -0.178 & $(0.279)$ & & & & & & & & \\
\hline radical & 0.585 & $(0.340)$ & & & & & & & & \\
\hline $\begin{array}{l}\text { challengers' previous action was } \\
\text { the same }\end{array}$ & & & 0.060 & $(0.545)$ & $1.187^{* *}$ & $(0.428)$ & $2.240^{* * *}$ & $(0.501)$ & 1.303 & $(0.909)$ \\
\hline Constant & 0.854 & $(0.519)$ & $-4.253^{* * *}$ & $(0.577)$ & $-1.523^{* *}$ & $(0.525)$ & $-1.406^{* * *}$ & $(0.395)$ & $-1.581^{*}$ & $(0.683)$ \\
\hline r2_p & 0.10 & & 0.11 & & 0.17 & & 0.08 & & 0.21 & \\
\hline II & -1583.69 & & -404.81 & & -747.52 & & -1109.09 & & -281.07 & \\
\hline $\mathrm{N}$ & 2555 & & 2555 & & 2401 & & 2514 & & 2269 & \\
\hline \multicolumn{11}{|l|}{ Actions only } \\
\hline government repression & -0.056 & $(0.384)$ & & & 0.318 & $(0.361)$ & -0.090 & $(0.524)$ & $-1.899^{* * *}$ & (0.181) \\
\hline third party support & -0.023 & $(0.248)$ & -0.480 & $(0.532)$ & $0.862^{* *}$ & $(0.320)$ & -0.149 & $(0.300)$ & -0.916 & $(0.755)$ \\
\hline sequence length in levels & -0.017 & $(0.042)$ & 0.026 & $(0.069)$ & $0.122^{+}$ & $(0.070)$ & $-0.077^{+}$ & $(0.043)$ & -0.074 & (0.069) \\
\hline sequence length squared & 0.000 & $(0.001)$ & -0.000 & $(0.002)$ & $-0.005^{*}$ & $(0.002)$ & 0.002 & $(0.001)$ & 0.002 & (0.002) \\
\hline \multicolumn{11}{|l|}{$\begin{array}{l}\text { Challengers' lagged action (none) } \\
\text { (REF) }\end{array}$} \\
\hline Cooperation & 0.174 & $(0.412)$ & & & & & & & & \\
\hline Non-radical & -0.022 & $(0.305)$ & & & & & & & & \\
\hline radical & $0.708^{+}$ & $(0.425)$ & & & & & & & & \\
\hline
\end{tabular}




\begin{tabular}{|c|c|c|c|c|c|c|c|c|c|c|}
\hline $\begin{array}{l}\text { challengers' previous action was } \\
\text { the same } \\
\text { Constant }\end{array}$ & 0.270 & $(0.364)$ & $-4.329^{* * *}$ & $(0.830)$ & $\begin{array}{c}0.989^{*} \\
-2.067^{* * *}\end{array}$ & $\begin{array}{l}(0.391) \\
(0.442)\end{array}$ & $\begin{array}{l}2.154^{* * *} \\
-1.592^{* * *}\end{array}$ & $\begin{array}{l}(0.500) \\
(0.412)\end{array}$ & $\begin{array}{l}1.524^{+} \\
-1.443^{*}\end{array}$ & $\begin{array}{l}(0.901) \\
(0.647)\end{array}$ \\
\hline r2_p & 0.08 & & 0.09 & & 0.19 & & 0.10 & & 0.21 & \\
\hline II & -1441.71 & & -290.93 & & -504.50 & & -941.77 & & -252.29 & \\
\hline $\mathrm{N}$ & 2555 & & 2406 & & 2401 & & 2514 & & 1950 & \\
\hline
\end{tabular}

Significance levels: $+. \mathrm{p}<=0.1 ; * \mathrm{p}<=0.05 ; * * \mathrm{p}<=0.01 ; * * \mathrm{p}<=0.001$; country effects omitted from the table. 
Table A10.2: effects of interaction between government repression and episodes classified according to actors' configurations

\begin{tabular}{|c|c|c|c|c|c|c|c|c|c|c|}
\hline & \multicolumn{2}{|c|}{$\begin{array}{l}\text { Model } 1 \text { any form of } \\
\text { mobilization }\end{array}$} & \multicolumn{2}{|c|}{$\begin{array}{c}\text { Model } 2 \text { conventional } \\
\text { actions }\end{array}$} & \multicolumn{2}{|c|}{$\begin{array}{c}\text { Model } 3 \text { demonstrative } \\
\text { forms }\end{array}$} & \multicolumn{2}{|c|}{ Model 4 strikes } & \multicolumn{2}{|c|}{$\begin{array}{l}\text { Model } 5 \\
\text { confrontational and } \\
\text { violent actions }\end{array}$} \\
\hline & $b$ & se & $b$ & se & $b$ & se & $b$ & se & $b$ & se \\
\hline $\begin{array}{l}\text { government repression } \\
\text { Party episode (REF) }\end{array}$ & $-0.907^{* *}$ & $(0.350)$ & -0.730 & $(0.604)$ & $-1.558^{* * *}$ & (0.429) & 1.580 & $(1.122)$ & $-0.512^{+}$ & $(0.294)$ \\
\hline Trade unions episode & $0.890^{*}$ & $(0.355)$ & -0.389 & $(0.662)$ & -0.400 & $(0.296)$ & $3.617^{* * *}$ & $(0.671)$ & $3.277^{*}$ & $(1.357)$ \\
\hline $\begin{array}{l}\text { SMOs episode } \\
\text { Repression*Party episode (REF) }\end{array}$ & $1.263^{* * *}$ & $(0.364)$ & -0.299 & $(0.485)$ & $0.734^{*}$ & $(0.306)$ & $2.700^{* * *}$ & $(0.710)$ & 1.819 & $(1.326)$ \\
\hline Repression*Trade unions episode & $1.389^{* *}$ & $(0.455)$ & & & $1.803^{* * *}$ & $(0.520)$ & -1.344 & $(1.162)$ & & \\
\hline $\begin{array}{l}\text { Repression*CSOs episode } \\
\text { Challengers' lagged action } \\
\text { (none)(REF) }\end{array}$ & 0.541 & $(0.390)$ & 1.006 & (0.909) & $1.029^{*}$ & $(0.525)$ & -1.309 & $(1.237)$ & & \\
\hline Cooperation & 0.191 & $(0.374)$ & & & & & & & & \\
\hline Non-radical & -0.146 & $(0.249)$ & & & & & & & & \\
\hline radical & 0.446 & $(0.323)$ & & & & & & & & \\
\hline $\begin{array}{l}\text { challengers' previous action was } \\
\text { the same }\end{array}$ & & & 0.091 & $(0.557)$ & $2.143^{* * *}$ & $(0.481)$ & $1.116^{*}$ & $(0.476)$ & 1.264 & $(0.914)$ \\
\hline third party support & 0.218 & $(0.246)$ & -0.454 & $(0.644)$ & -0.039 & $(0.245)$ & $1.071^{*}$ & $(0.439)$ & $-1.012^{*}$ & $(0.488)$ \\
\hline sequence length in levels & 0.021 & $(0.043)$ & 0.060 & $(0.086)$ & -0.029 & $(0.045)$ & 0.078 & $(0.067)$ & 0.003 & $(0.062)$ \\
\hline sequence length squared & -0.002 & $(0.001)$ & -0.002 & $(0.003)$ & -0.000 & $(0.001)$ & $-0.004^{*}$ & $(0.002)$ & -0.000 & $(0.002)$ \\
\hline Constant & 0.052 & $(0.516)$ & $-3.972^{* * *}$ & $(0.707)$ & $-1.407^{* *}$ & $(0.465)$ & $-4.791^{* * *}$ & $(0.813)$ & $-4.631^{* *}$ & $(1.411)$ \\
\hline r2_p & 0.12 & & 0.10 & & 0.11 & & 0.23 & & 0.26 & \\
\hline II & -1541.29 & & -401.40 & & -1077.26 & & -700.06 & & -259.57 & \\
\hline $\mathrm{N}$ & 2555 & & 2438 & & 2514 & & 2401 & & 2177 & \\
\hline
\end{tabular}


Table A10.3: effects of government repression on challengers' protests actions and threats (upper table) and actions only (lower table), Greece

\begin{tabular}{|c|c|c|c|c|c|c|c|c|c|c|}
\hline & \multicolumn{2}{|c|}{$\begin{array}{c}\text { Model } 1 \text { any form of } \\
\text { protest }\end{array}$} & \multicolumn{2}{|c|}{$\begin{array}{l}\text { Model } 2 \text { conventional } \\
\text { actions }\end{array}$} & \multicolumn{2}{|c|}{ Model 3 strikes } & \multicolumn{2}{|c|}{$\begin{array}{c}\text { Model } 4 \\
\text { demonstrative forms }\end{array}$} & \multicolumn{2}{|c|}{$\begin{array}{l}\text { Model } 5 \text { radical } \\
\text { actions }\end{array}$} \\
\hline & $b$ & se & $b$ & se & $b$ & se & $b$ & se & $b$ & se \\
\hline $\begin{array}{l}\text { Actions and threats } \\
\text { government repression }\end{array}$ & $0.516^{+}$ & $(0.289)$ & 1308 & $(0.967)$ & 0.466 & $(0.352)$ & -0.383 & $(0.354)$ & -0.538 & $(0.425)$ \\
\hline third party support & $0.869^{* * *}$ & $(0.224)$ & -0.071 & $(0.857)$ & $1.758^{* * *}$ & $(0.263)$ & -0.233 & $(0.258)$ & $-1.240^{* * *}$ & $(0.314)$ \\
\hline sequence length in levels & -0.047 & $(0.064)$ & -0.024 & $(0.146)$ & $-0.157^{*}$ & $(0.069)$ & -0.068 & $(0.063)$ & -0.105 & (0.073) \\
\hline sequence length squared & 0.001 & $(0.002)$ & 0.001 & $(0.004)$ & 0.002 & $(0.002)$ & 0.001 & $(0.002)$ & 0.002 & $(0.002)$ \\
\hline Challengers' lagged action (none)(REF) & & & & & & & & & & \\
\hline Cooperation & $-1.048^{+}$ & $(0.607)$ & & & & & & & & \\
\hline Non-radical & $-1.734^{* * *}$ & $(0.465)$ & & & & & & & & \\
\hline radical & -0.607 & $(0.497)$ & & & & & & & & \\
\hline $\begin{array}{l}\text { challengers' previous action was the } \\
\text { same }\end{array}$ & & & & & $1.379^{* * *}$ & $(0.352)$ & $2.314^{* * *}$ & $(0.339)$ & $2.174^{* * *}$ & $(0.434)$ \\
\hline Constant & $1.192^{* * *}$ & $(0.343)$ & $-4.313^{* * *}$ & $(1.080)$ & $-0.737^{*}$ & $(0.369)$ & $-1.513^{* * *}$ & $(0.389)$ & $-1.022^{*}$ & $(0.416)$ \\
\hline r2_p & 0.11 & & 0.03 & & 0.20 & & 0.15 & & 0.14 & \\
\hline ॥ & -271.41 & & -29.39 & & -224.97 & & -196.51 & & -151.89 & \\
\hline $\mathrm{N}$ & 472.00 & & 356.00 & & 472.00 & & 472.00 & & 472.00 & \\
\hline $\begin{array}{l}\text { Actions only } \\
\text { repression }\end{array}$ & $0.778^{+}$ & $(0.454)$ & & & $0.883^{+}$ & $(0.480)$ & -0.015 & $(0.496)$ & $-1.887^{+}$ & (1.059) \\
\hline third party support & 0.134 & (0.198) & -0.282 & $(0.825)$ & $1.091^{* * *}$ & $(0.260)$ & -0.227 & $(0.261)$ & $-1.248^{* * *}$ & $(0.321)$ \\
\hline sequence length in levels & 0.023 & $(0.059)$ & 0.020 & $(0.144)$ & -0.035 & $(0.073)$ & -0.078 & $(0.062)$ & -0.119 & $(0.075)$ \\
\hline sequence length squared & -0.000 & $(0.001)$ & 0.000 & $(0.004)$ & -0.001 & $(0.002)$ & 0.002 & $(0.002)$ & 0.002 & (0.002) \\
\hline Challengers' lagged action (none)(REF) & & & & & & & & & & \\
\hline Cooperation & -0.923 & $(0.574)$ & & & & & & & & \\
\hline Non-radical & $-1.210^{* *}$ & $(0.429)$ & & & & & & & & \\
\hline radical & -0.523 & $(0.458)$ & & & & & & & & \\
\hline $\begin{array}{l}\text { challengers' previous action was the } \\
\text { same }\end{array}$ & & & & & $0.998^{* *}$ & $(0.348)$ & $2.320^{* * *}$ & $(0.340)$ & $2.334^{* * *}$ & $(0.449)$ \\
\hline Constant & 0.220 & $(0.301)$ & $-4.230^{* * *}$ & $(1.073)$ & $-1.453^{* * *}$ & $(0.402)$ & $-1.620^{* * *}$ & $(0.395)$ & $-1.008^{*}$ & $(0.422)$ \\
\hline r2_p & 0.03 & & 0.01 & & 0.10 & & 0.15 & & 0.15 & \\
\hline
\end{tabular}




\begin{tabular}{|c|c|c|c|c|c|}
\hline$\|$ & -316.33 & -30.01 & -220.31 & -190.65 & -145.55 \\
\hline $\mathrm{N}$ & 472 & 346 & 472 & 472 & 472 \\
\hline
\end{tabular}


Table A10.4: effects of interactions between government's repression and type of cabinet

\begin{tabular}{|c|c|c|c|c|c|c|c|c|c|c|}
\hline & \multicolumn{2}{|c|}{$\begin{array}{c}\text { Model } 1 \text { any form of } \\
\text { mobilization }\end{array}$} & \multicolumn{2}{|c|}{$\begin{array}{c}\text { Model } 2 \text { conventional } \\
\text { actions }\end{array}$} & \multicolumn{2}{|c|}{$\begin{array}{c}\text { Model } 3 \\
\text { demonstrative forms }\end{array}$} & \multicolumn{2}{|c|}{ Model 4 strikes } & \multicolumn{2}{|c|}{$\begin{array}{c}\text { Model } 5 \\
\text { confrontational and } \\
\text { violent actions }\end{array}$} \\
\hline & $b$ & se & $b$ & se & $b$ & se & $b$ & se & $\mathrm{b}$ & se \\
\hline government repression & -0.088 & $(0.390)$ & $-1.342^{*}$ & (0.605) & -0.386 & $(0.282)$ & 0.809 & $(0.590)$ & $-0.463^{*}$ & (0.208) \\
\hline left cabinet & -0.447 & $(0.302)$ & -0.320 & $(0.755)$ & -0.222 & $(0.294)$ & 0.345 & $(0.351)$ & $-2.433^{* * *}$ & (0.684) \\
\hline $\begin{array}{l}\text { Repression*left cabinet } \\
\text { Challengers' lagged action (none) } \\
\text { (REF) }\end{array}$ & -0.053 & $(0.417)$ & $1.679^{+}$ & (0.991) & 0.104 & $(0.345)$ & -1.062 & $(0.701)$ & -1.121 & (0.939) \\
\hline Cooperation & 0.409 & $(0.414)$ & & & & & & & & \\
\hline Non-radical & -0.142 & $(0.268)$ & & & & & & & & \\
\hline radical & $0.569^{+}$ & (0.339) & & & & & & & & \\
\hline $\begin{array}{l}\text { challengers' previous action was } \\
\text { the same }\end{array}$ & & & 0.035 & $(0.564)$ & $2.230^{* * *}$ & $(0.513)$ & $1.238^{* *}$ & $(0.432)$ & 1.307 & (0.994) \\
\hline third party support & 0.365 & (0.289) & -0.412 & $(0.655)$ & -0.100 & $(0.280)$ & $1.152^{* *}$ & $(0.387)$ & 0.448 & $(0.442)$ \\
\hline sequence length in levels & 0.006 & $(0.048)$ & 0.067 & $(0.090)$ & -0.057 & $(0.044)$ & 0.071 & $(0.066)$ & -0.009 & $(0.083)$ \\
\hline sequence length squared & -0.001 & $(0.001)$ & -0.002 & $(0.003)$ & 0.001 & $(0.002)$ & $-0.004^{+}$ & $(0.002)$ & -0.000 & $(0.002)$ \\
\hline Constant & $1.179^{*}$ & $(0.499)$ & $-4.164^{* * *}$ & $(0.644)$ & $-1.262^{* * *}$ & $(0.367)$ & $-1.752^{* *}$ & $(0.550)$ & -0.509 & (0.573) \\
\hline r2_p & 0.10 & & 0.11 & & 0.08 & & 0.18 & & 0.28 & \\
\hline$\|$ & -1576.33 & & -403.33 & & -1107.93 & & -743.70 & & -254.70 & \\
\hline $\mathrm{N}$ & 2555 & & 2555 & & 2514 & & 2401 & & 2269 & \\
\hline
\end{tabular}


Table A10.5: effects of interaction of government repression and international allies

\begin{tabular}{|c|c|c|c|c|c|c|c|c|c|c|}
\hline & \multicolumn{2}{|c|}{$\begin{array}{l}\text { Model } 1 \text { any form of } \\
\text { mobilization }\end{array}$} & \multicolumn{2}{|c|}{$\begin{array}{l}\text { Model } 2 \text { conventional } \\
\text { actions }\end{array}$} & \multicolumn{2}{|c|}{$\begin{array}{c}\text { Model } 3 \\
\text { demonstrative forms }\end{array}$} & \multicolumn{2}{|c|}{ Model 4 strikes } & \multicolumn{2}{|c|}{$\begin{array}{c}\text { Model } 5 \\
\text { confrontational and } \\
\text { violent actions }\end{array}$} \\
\hline & $\mathrm{b}$ & se & $\mathrm{b}$ & se & $\mathrm{b}$ & se & $\mathrm{b}$ & se & $\mathrm{b}$ & se \\
\hline government repression & 0.167 & $(0.399)$ & $-1.796^{+}$ & $(0.943)$ & -0.193 & $(0.281)$ & 0.949 & $(0.662)$ & $-0.487^{* *}$ & $(0.163)$ \\
\hline Gov-international alliances & -0.400 & $(0.347)$ & -0.691 & $(0.702)$ & -0.131 & $(0.376)$ & 0.364 & $(0.485)$ & $-2.330^{* * *}$ & $(0.644)$ \\
\hline $\begin{array}{l}\text { Chall-international alliances } \\
\text { No alliances (REF) }\end{array}$ & 0.328 & $(0.474)$ & -0.179 & $(0.541)$ & 0.085 & $(0.393)$ & -0.435 & $(0.626)$ & $0.866^{+}$ & $(0.459)$ \\
\hline $\begin{array}{l}\text { Repression* Gov-international } \\
\text { alliances }\end{array}$ & -0.535 & $(0.482)$ & $2.455^{*}$ & $(1.207)$ & -0.330 & (0.359) & -1.153 & $(0.764)$ & -0.961 & $(0.903)$ \\
\hline $\begin{array}{l}\text { Repression* Chall-international } \\
\text { alliances } \\
\text { Repression* No alliances (REF) } \\
\text { Challengers' lagged action (none)(REF) }\end{array}$ & -0.735 & $(0.689)$ & 0.911 & $(1.246)$ & -0.324 & $(0.547)$ & -0.600 & $(0.980)$ & & \\
\hline Cooperation & 0.269 & $(0.418)$ & & & & & & & & \\
\hline Non-radical & -0.140 & $(0.275)$ & & & & & & & & \\
\hline radical & 0.547 & $(0.350)$ & & & & & & & & \\
\hline $\begin{array}{l}\text { challengers' previous action was the } \\
\text { same }\end{array}$ & & & 0.037 & $(0.572)$ & $2.230^{* * *}$ & $(0.505)$ & $1.226^{* *}$ & $(0.427)$ & 1.297 & $(1.046)$ \\
\hline third party support & 0.464 & $(0.300)$ & -0.250 & $(0.730)$ & -0.089 & $(0.268)$ & $0.983^{*}$ & $(0.395)$ & $1.026^{* *}$ & $(0.337)$ \\
\hline sequence length in levels & 0.015 & $(0.046)$ & 0.076 & $(0.085)$ & -0.054 & $(0.044)$ & 0.055 & $(0.071)$ & 0.036 & $(0.113)$ \\
\hline sequence length squared & -0.001 & $(0.001)$ & -0.002 & $(0.003)$ & 0.001 & $(0.002)$ & -0.003 & $(0.002)$ & -0.002 & $(0.003)$ \\
\hline Constant & $1.019^{+}$ & $(0.577)$ & $-4.024^{* * *}$ & $(0.752)$ & $-1.352^{*}$ & $(0.536)$ & $-1.543^{*}$ & $(0.649)$ & -1.420 & $(0.981)$ \\
\hline r2_p & 0.11 & & 0.12 & & 0.08 & & 0.18 & & 0.31 & \\
\hline ॥ & -1571.01 & & -401.10 & & -1108.07 & & -740.55 & & -244.51 & \\
\hline $\mathrm{N}$ & 2555 & & 2555 & & 2514 & & 2401 & & 2162 & \\
\hline
\end{tabular}

Significance levels: $+. \mathrm{p}<=0.1 ; * \mathrm{p}<=0.05 ; * * \mathrm{p}<=0.01 ; * * * \mathrm{p}<=0.001 ;$ country effects omitted from the table. 


\section{References}

Ancelovici, Marcos. 2011. "In search of lost radicalism. The Hot Autumn of 2010 and the Transformation of Labor Contention in France". French Politics, Culture \& Society 29(3): 121-140.

della Porta, Donatella. 1995. Social Movements, Political Violence, and the State: A Comparative Analysis of Italy and Germany. New York: Cambridge University Press.

della Porta, Dontella. 2015. Social Movements in Times of Austerity: Bringing Capitalism Back Into Protest Analysis, Cambridge: Polity Press.

Duboc, Marie. 2011. “Egyptian Leftist Intellectuals' Activism from the Margins: Overcoming the Mobilization/Demobilization Dichotomy”. Pp. 61-79 in Social movements, mobilization, and contestation in the Middle East and North Africa, edited by Beinin, J. and Vairel, F. Stanford: Stanford University Press.

Earl, Jennifer. 2011. "Political Repression: Iron Fists, Velvet Gloves, and Diffuse Control” Annual Review of Sociology, 37 (1): 261-284.

Gurr, Ted. 1970. Why men rebel? Princeton: Princeton. University Press

Koopmans, Ruud, Paul Statham, Marco G. Giugni and Florence Passy. 2005. Contested Citizenship: Immigration and Cultural Diversity in Europe. Minneapolis: University of Minnesota Press.

Kriesi, Hanspeter, Ruud Koopmans, Jan Willem Duyvendak, and Marco G.Giugni. 1995., New Social Movements in Western Europe: A Comparative Analysis. Minneapolis: University of Minnesota Press.

Kriesi, H., Lorenzini, J., Wüest, B., \& Hausermann, S. (Eds.). (2020). Contention in Times of Crisis: Recession and Political Protest in Thirty European Countries. Cambridge: Cambridge University Press.

Lichbach, Mark I. 1987. “Deterrence or Escalation? The puzzle of Aggregate Studies of Repression and Dissent." The Journal of conflict Resolution 31 (2): 266-297.

Lichbach, Mark I., and Ted R. Gurr. 1981.” The Conflict Process A Formal Model.” Journal of Conflict Resolution 25 (1): 3-29.

McAdam, Doug. 1996. "Conceptual origins, current problems, future directions” Pp. 23-40 in Comparative Perspectives on Social Movements: Political Opportunities, Mobilizing Structures, and 
Cultural Framings, edited by D. McAdam, J.D. McCarthy, and M.N. Zald. Cambridge, Cambridge University Press.

Oberschall, Anthony. 1973. Social movements and social conflict. Englewood Cliffs: Prentice-Hall.

Pilati, Katia. 2016. "Do organizational structures matter for protests in non-democratic African countries?" Pp. 46-72 in Contention, regimes, and transition - Middle East and North Africa protest in comparative perspective, edited by E. Y. Alimi, A. Sela, \& M. Sznajder. Oxford: Oxford University Press.

Portos García, Martin. 2016. "Taking to the streets in the context of austerity: a chronology of the cycle of protests in Spain, 2007-2015”. Partecipazione e conflitto, 9 (1): 181-210.

Sotirakopoulos, Nikos and Georg Sotiropoulos. 2013. “ 'Direct democracy now!': The Greek indignados and the present cycle of struggles." Current Sociology 61(4): 443-456. https://doi.org/10.1177/0011392113479744

Tarrow, Sidney. 1989. Democracy and disorder: protest and politics in Italy, 1965-1975. Oxford: Clarendon Press; New York: Oxford University Press.

Tilly, Charles. 1978. From Mobilization to Revolution. Reading, Mass.: Addison-Wesley.

Tilly, Charles. 2005. Repression, mobilization, and explanation, pp. 211-226 in Repression and Mobilization, edited by Christian Davenport, Hank Johnston and Carol Mueller, Minneapolis: University of Minnesota Press.

Tilly, Charles. 2006. Regimes and Repertoires. Chicago: Chicago University Press.

Tilly, Charles. 2008. Contentious Performances. New York: Cambridge University Press. 